\title{
Introduction \\ The Politics of International Political Theory
}

Anthony F Lang, Jr. and

Mathias Albert

Chris Brown has been one of the most important figures in constituting International Political Theory (IPT). Others have played crucial roles as well, including some of those included in this volume. Yet it is Brown, arguably, who has been central to putting political theory in conversation with international relations theory. His ability to synthesize, critically assess and push the boundaries of these adjacent theoretical perspectives has helped to frame world politics in ways that go beyond traditional and often staid debates. Perhaps even more importantly, Brown has connected sophisticated theoretical debates, both in contemporary and historical theory, with pressing dilemmas of global politics in the current age. He has consistently refused to keep theory distinct from the 'world' and has also refused to let the 'world' of politics resist normative theorizing. In so doing, he has brought forth the centrality of 'judgment', the ability to draw upon forms of political wisdom and use them to critique political practice. The cultivation of judgment about world politics is where Brown's IPT makes its most distinctive mark.

This introductory chapter will situate Brown's work in relation to wider themes in IPT. We provide some context to Brown's development as a scholar, looking to the ways in which his ideas emerged in relation to different debates in both political theory and international relations. The first section provides a brief intellectual biography. The second section explores the idea of IPT through an engagement with three books through which he has defined the field: International Relations Theory: New Normative Approaches (IRT) (1992); Sovereignty, Rights and Justice (SRJ) (2001) and International Society, Global Polity: An Introduction to International Political Theory (ISGP) (2015). In the first work, he poses communitarianism against cosmopolitanism, in the second he poses sovereignty against 
rights, and in the third he poses international society against global polity. ${ }^{1}$ These overlapping frames, while different in important ways, reflect a core facet of Brown's approach negotiating the space between a world of states and a world of individuals. This structure remains at the heart of many treatments of IPT, and has, as such, shaped the theoretical orientation of many in the field. As Brown has moved away from his initial framing of the field in this way, this section instead looks more directly to how he understands the task of IPT; that is, how he moves from an idea of 'normative theory' to IPT. We will also briefly address the issue of Brown's relation to the 'English School' of International Relations in this context, as this is an approach which also seeks to locate a relationship between the individual and the state, especially with the emergence of recent debates about 'world society' (Buzan 2004).

The next part of the introduction looks to his engagement with the predominant liberal international order, particularly the ways in which powerful states in the Atlantic and wider European context have shaped discourses of human rights, humanitarian intervention, and the use of military force. This section looks to how Brown both defends and critiques liberal internationalism. For instance, he has argued in defence of human rights, yet also pointed out that such rights cannot work without developing cultural frameworks that enable the practice of such rights (Brown 2010b). He has defended the importance of a global polity in which rights and democracy are prominent, yet also noted that objections to universalism is not the result of simple selfish interests, but arises from a principled resistance to colonialism and a valid moral defence of sovereignty (Brown 2015: 216). It explores briefly his reflections on cultural pluralism, an issue that animates a great deal of his work.

\footnotetext{
${ }^{1}$ The books include much more than these simple dichotomies, and Brown has sought to resist the 'cosmopolitan vs communitarian' framework as the defining feature of his work and or IPT.
} 
The concluding section of the introduction turns to the theme of political judgment, which appears throughout his career and especially in the collection of essays entitled Practical Judgment in International Political Theory: Selected Essays (2010). Brown draws his idea of judgment from a broadly Aristotelian account, though he is by no means confined to the ancient Greek understanding of this term. Rather, perhaps inspired by Aristotle rather than following him, Brown points to the contextual process by which individuals in positions of leadership must make decisions about difficult matters. But those decisions are not simply for leaders. He writes for a wider audience than just the elites, having published books for classroom use, including his bestselling textbook, Understanding International Relations, $4^{\text {th }}$ ed (Brown and Ainley 2009). He argues he is in the business of 'public education' which is relevant for the student as much as for the leader, suggesting that 'we must try to cultivate the faculty for judgment in ourselves that we hope [political leaders] will also cultivate' (Brown 2010: 249).

\section{Intellectual Biography}

One of the defining features of Brown's scholarship is that he is grounded in both historical and contemporary international affairs. Indeed, he notes that 'anyone who wishes to be taken seriously as a theorist of international relations had better be steeped in international history and have a very good knowledge of current affairs as well as a familiarity with the classics of political thought' (Brown 2010: 3). Theorists of IPT have benefited from this grounding not only by reading his work, but taking his classes, engaging with him at conferences, and even interacting with him on social media. In all these realms, Brown refuses to remain in the world of pure theory (though he is well-grounded in this as well, as will become evident below) but demands that theorists take seriously the tensions and complexities of the contemporary international order. 
This grounding in politics and history comes, perhaps, from the trajectory by which Brown became part of academia. ${ }^{2}$ In 1963, upon graduation from secondary school, Brown entered the Ministry of Housing and Local Government. He wished to study history, so after receiving very strong exam marks, the Civil Service gave him three years leave to pursue a university degree, which Brown undertook at the London School of Economics. While at LSE, he fell under the influence of Philip Windsor and so transferred to International Relations. After receiving a First (a much more difficult achievement at that time than it is in the modern British university), Brown received a scholarship from the Ford Foundation funded Centre for International Studies at LSE, and so began work toward his $\mathrm{PhD}$.

Brown took up a post at Kent University before completing his PhD. In fact, he abandoned his thesis, which was on uses of history in international theory and the rise of post-behaviourist scholarship, a topic which informs some of his scholarship to this day. He realized in the 1990 s that having a $\mathrm{PhD}$ might be a benefit, so took one on the basis of his then recently published book, International Theory: New Normative Perspectives (1992) through a staff scheme at Kent. Outside of a short stint as a visiting lecturer at the University of Massachusetts, Amherst, Brown remained at Kent until 1994. For four years, he was Professor of Politics at Southampton University, then was appointed to a chair in International Relations at the LSE in 1998, where he remained until his retirement in 2014. Brown published only a few works during his early career, a period which allowed him to read widely and deeply across political theory and international relations, something he notes is less available to many scholars today in academia as the pressure to publish has become intense (Brown 2010: 3). Brown's ability to speak to so many different theoretical traditions and connect those with contemporary political events both domestic and international reflects the benefits of reading before seeking to publish. He also notes that he

\footnotetext{
${ }^{2}$ See Brown's description of his intellectual trajectory in Brown 2010: 1-16.
} 
benefited greatly from colleagues outside of his department as well as inside at Kent University, for they provided him insights into trends in the humanities that enabled him to better appreciate postmodern theoretical developments. The increasingly specialized nature of academic scholarship today militates against such humanistic learning, a fact that contemporary scholars of IPT should recognize and perhaps work toward altering. One might argue that IPT can only work within a humanistic approach, for it requires training and knowledge of such a range of different theoretical ideas.

This background knowledge was further enhanced during his time in the United States, where he shared a department with Jean Bethke Elshtain and William Connolly during the academic year 1981-1982 the former a leading feminist (and later realist) thinker of international relations and the latter one of the most important postmodernist political theorists whose work continues to inform scholars in IR. Brown notes that Connolly has been a major influence on this thinking, particularly in coming to grips with the complexity of pluralism within liberal societies, though it is unclear whether or not Brown would continue to follow some of Connolly's political and theoretical ideas (Brown 2010: 4).

Brown published only one journal article and one report in the 1970 s, both on International Political Economy (IPE). These publications came, in part, through the influence of Susan Strange, who was seeking to develop IPE as a separate field within IR. Brown's work returns to Strange at different points in his career (e.g., Brown 2002: 232-235), though perhaps her bigger influence is that, like Brown, she sought to carve out a space within a dominant discourse for an alternative framing of IR. Beginning with his 1981 publication in the Review of International Studies (Brown 1981), Brown began to push IR scholars to a greater engagement with political and ethical theory. This work culminated in his book, International Relations Theory: New Normative Approaches (Brown 1992), which set the stage for his framing of IPT, explored in more detail in the next section. 


\section{Framing and Reframing IPT}

As noted in the introduction to this chapter, three of Brown's books constitute a theoretical framework that integrates a range of theoretical positions in order to better understand and evaluate international relations. Only the third is written explicitly as a textbook, though really all three do not fall easily into a 'textbook' or 'monograph' category; undoubtedly, this reflects Brown's approach to his career, where teaching and research inform each other. Brown has authored a bestselling general IR textbook as well, Understanding International Relations, now in its fourth edition (2009). This text should not be ignored in developing an understanding of how Brown conceives of IPT, for it presents IR theory as including ethical dimensions, something that many other textbooks refuse to do, though we do not address it here at any length. ${ }^{3}$

In IRT, Brown proposes a conceptual distinction between cosmopolitanism and communitarianism as a way to categorize thinking within IR theory. This framing does not capture all the possible theories, but Brown uses it to understand the competing normative orientations that underlie IR theories. But because he largely leaves this framework behind, a better focus is on how he understands the task of IPT. This requires appreciating his initial approach to the idea of what it means to do 'normative' theory. In IRT, he defines it in this way:

By normative international relations theory is meant that body of work which addresses the moral dimension of international relations and the wider questions of meaning and interpretation generated by the discipline. At its most basic it addresses the ethical nature of the relations between communities/states, whether in the context of the old agenda, which focused on violence and war, or the new(er) agenda which mixes these traditional concerns with the modern demand for international distributive justice. (Brown 1992: 3)

\footnotetext{
${ }^{3}$ At the time of this writing, Brown is working on a revised $5^{\text {th }}$ edition of this textbook.
} 
Brown goes on to qualify this definition, noting that IR scholars have a resistance to the term normative, for it assumes that the role of such theory is to prescribe norms, and, as a result, that scholars in this realm have 'some special knowledge which enables them to solve the difficult moral dilemmas of the day' (ibid). He disabuses readers of this notion, pointing out that normative theorists might consider such ethical dilemmas and read through works which address such questions more than others, but, even if this is the case, "none of [this] amounts to any kind of right to prescribe' (ibid).

The concern expressed here brings forth an important dimension of Brown's work, one that not all normative theorists might accept. There has emerged, in recent years, a style of normative theory undertaken largely by political philosophers that does indeed seek to prescribe. Such works draw largely on analytical philosophical traditions of thought in which problems of war, peace, justice, and rights appear largely as problems of logic. It follows that, if careful thought is applied to these problems, shared conclusions will result. Brown's work does not fall into this category of scholarship, and he has been explicitly critical of it in areas such as just war (Brown 2017). As Brown argues, these matters cannot be solved simply by better logical thinking or analytical precision. Instead, such matters require a form of political judgement which results from study of not just abstract theory but concrete reality, philosophical tradition, and, perhaps, lived experience of political life. The question of judgment will be addressed later in this chapter, but it would seem to be prefigured by this caution about defining normative theory early on his scholarship.

In defining his task in this way, Brown helpfully locates not just normative theorists but assumptions that orient much of the wider scholarship in IR. For instance, the importance of the national interest to many realist scholars relies on a valuation of the sovereign state over other institutional forms. While classical realists such as Hans Morgenthau and George Kennan were explicit about the moral value of the state (see Lang 2007), the same moral 
assumptions, usually unacknowledged, underlie much of the research agendas of neorealist scholars, such as Kenneth Waltz. This is not to disparage such works, but rather to highlight that their normative agendas should be acknowledged and perhaps better defended by those working these areas.

A second point arising from Brown's framing is that he undertakes it through an engagement with the history of political thought. In his influential co-edited volume of texts drawn from this history, Brown (along with Terry Nardin and Nicholas Rengger) contextualize and make relevant this history (Brown et al 2002). In his scholarship, this task is done rather lightly by Brown, in such a way that these historical figures inform his work without falling into a purely historicist approach. Brown uses these figures in such a way that it both reveals how IR theory might be inheritors of traditions which they may not know of and also, more importantly, engages in a dialogue with them. For instance, in the chapter on communitarianism in IRT, Brown engages in an extended discussion of G. W. F. Hegel. One way to read Hegel in the context of IR theory would be to locate the ways in which realists such as Morgenthau inherited a Hegelian state worship which has informed the study of IR ever since. This link Brown acknowledges, but he also explores the subtleties of Hegel's ideas in relation to other theorists, both those against whom Hegel was reacting and those who developed his ideas throughout the $19^{\text {th }}$ and $20^{\text {th }}$ centuries. ${ }^{4}$ Even more importantly, Brown does not simply accept Hegel's theories, but notes the difficulty of accepting a 'secular' Hegel (Brown 1992: 64). This critical encounter with Hegel suggests how Brown's work moves from 'normative IR theory' to International Political Theory; that is, instead of simply undertaking a history of political thought or IR theory, Brown is engaging in a critical dialogue with that history in order to better understand different positions within IR theory.

\footnotetext{
${ }^{4}$ Mervyn Frost is perhaps the most prominent Hegelian among IR theorists, who also contributes to this volume; see Frost 1986 and 1996.
} 
Brown concludes IRT with a discussion of what was at the time of his writing a new set of approaches in IR theory - critical and postmodern theory. He provides a nuanced and careful overview of such theories, highlighting their contributions to a more critical analytical approach to international politics. This overview is reduced to one paragraph in SRJ (Brown 2002: 17) and completely disappears from ISGP. He suggests that

Some of this work is certainly valuable, but, on the whole, it is regrettable that it has come to play so prominent a role [in IPT]. When difficult and complex ideas genuinely illuminate important topics they must be confronted, but difficulty for its own sake is not a virtue and the narcissistic, hermetic quality of much of this work limits its relevance. (Brown 2002: 17)

This critique of postmodern and critical theory reveals a further important point about Brown's approach to IPT. It is clear from his overview in IRT that Brown is well versed in this work; as noted above, William Connolly, a leading postmodernist theorist, was a crucial influence on Brown early on in his career. Unlike many today, Brown has read not just Richard Ashley and R.B.J. Walker but Jacques Derrida and Michel Foucault, along with their forebears such as Nietzsche. That is, rather than the derivative work which constitutes so much of postmodern IR theory, Brown highlights how important it is for theorists to read those who provided the foundations for this work. In addition, Brown's critique is not necessarily one of substance but of style. This point is not meant in a disparaging way about Brown. Instead, it indicates how important style is to his presentation of ideas. Any reader of Brown's work will recognize his ability to make complex theoretical arguments accessible and relevant, something that many theorists, whether they be analytic moral philosophers, postmodernists, or neorealists, fail to do. IPT is about reading and drawing from theorists across a wide spectrum without falling into an overly specialized discourse that fails to connect with issues and concerns of the contemporary condition.

SRJ continues with the broadly defined cosmopolitan/communitarian framework, though it largely eschews those terms; indeed, Brown argues that the distinction perhaps 
simplifies things more than clarifies (Brown 2002: 17; Brown 2010: 8). Instead, by locating sovereignty in relationship to rights, Brown points to the underlying moral frame of the community and the individual. Here we begin to see the influence of liberal thought on Brown's work, a topic explored in the next section. Brown also distinguishes this work from his previous one by seeking to set aside the idea of 'normative theory', suggesting that SRJ is about 'interpretation' (Brown 2002: 3). In so doing, and in highlighting the three terms sovereignty, rights and justice, this book has a stronger political theory orientation then the previous one. It is here that the idea of IPT begins to take shape as a conscious endeavour.

SRJ explores a number of important themes, some of which extend those previously addressed in IRT. Completed only weeks before the attacks of September 11, 2001, the book includes a short prologue addressing the significance of that event. At the same time, it notes that the work as it stands speaks directly to the underlying themes brought forth by the attacks and the ensuing debates about the clash of civilizations and the rise of violent non-state actors. The last three chapters explore cultural diversity and the state system, which became (and continue to be) directly relevant to the conflicts in Central Asia and the Middle East. One point he makes in responding to September 11 is directly relevant to how he understands IPT. He notes that Samuel Huntington's idea of a 'clash of civilizations' while raising an important point, simplifies and essentializes a number of complex themes which the field of IPT seeks to interpret. In response, Brown argues

One, possibly desirable, alternative to a clash of civilization is crosscultural dialogue - but only if it is understood that dialogue is not an easy option. The only dialogue worth having, that is not simply an exchange of clichés, is one in which all the parties examine critically, as well as set out, their own values. 'Westerners' must examine their role in the various conflicts that poison Middle Eastern politics, and must address the demands for global social justice that emanate from the losers in today's world economy, but, equally, Muslims must ask themselves whether it is really plausible that all the woes of the socalled world of Islam are the responsibility of America, and, in particular, whether the savage theology of the al-Qaeda network and 
the Taliban deserves the respect it receives in many mosques and in the independent Arab media. (Brown 2002: xii)

This is a powerful call to those interested in international relations to avoid simplicity on either side of the debate. Asking all interested parties to critically assess and, perhaps more importantly, set out value orientations is a challenge and an opportunity. Brown's efforts to set out the 'Western' tradition reflects one side of this approach, and his request that others do the same from within their own traditions represents a more vigorous and robust form of IPT than is sometimes found in efforts at interfaith dialogue or comparative political theory.

His most recent book of IPT is the one most explicitly presented as a textbook. International Society, Global Polity (2016) moves his framing further away from the cosmopolitan/communitarian structure found in IRT. Instead, ISGP presents the issues of war, justice, and human rights through the framework of a society of states versus a global polity of agents which includes states but also puts individuals and other actors forward as important parts of the international system. International society draws on both international law and the 'English School' theories of IR, bringing them together in a creative way to understand the use of force, human rights, and humanitarian intervention. The global polity idea is not a purely cosmopolitan alternative, however, for Brown notes that to see the world as a global polity does not remove states but understands them as one among many agents in the international order. It does, however, like cosmopolitanism, put the individual person first and understands that person's rights and responsibilities differently than a purely society of states approach. In so doing, Brown is able to reframe issues such as distributive justice, international criminal law, and humanitarian intervention in new and interesting ways.

This alternative framing reminds IPT theorists of the importance of certain strands in IR theory. At one level, this should not be surprising, for Brown has always seen IPT as related to IR theory. But, for some who come to IPT from disciplines such as philosophy and who adopt more strictly liberal cosmopolitan orientations, the idea of a society of states makes 
little or no sense. As such, Brown's framing here provides an alternative to some of the staid debates about just war, distributive justice and human rights that often animate such theorists. In some sense, Brown's approach in this book is to look at the same issues and events through the two different framing prisms, resulting in, for instance, two parallel discussions of intervention and humanitarianism. Importantly, his argument is not a progressive one in which the society of states is replaced by the global polity; rather, his argument is that the two sit side by side in the world order and result in conflicting understandings and moral valuations of what is going on around us.

One interesting question in this context, and one certainly also entertained by the title of International Society, Global Polity, is whether Brown - or, more correctly: Brown-style IPT - actually is part of the so-called 'English School' of International Relations. While opinions on this issue vary, and the question about membership might not be that useful if the person in question repeatedly insists that he is not a member, the English School certainly features prominently in Brown's thought. While not counting him in the inner circle, Buzan's bookkeeping on the subject lists him as 'regular contributor', the definition of which being someone who has 'written three or more substantial items directly on English school topics' (Buzan 2014: 1)..

We argue that Chris Brown's relation to the English School can best be described by three characteristics: Firstly, he seems to broadly agree that the analytical triptych of an international system (of states), and international society (of states), and a world society and/or community (of, according to version, non-states only or non-states and states together) is a useful figure for describing the social orders of international relations. However, secondly, he remains critical of the English School's emphasis on international society in this context. This criticism pertains not primarily to empirical diagnoses about the existence of a social formation that can be described as an international society of states. Rather, in a 
criticism that actually resonates with much of Brown's criticism of IR theory that is not IPT, her argues 'that an approach that places primary emphasis on the nature of international society is likely to isolate itself from the wider discourses of political and social philosophy in ways that cannot be defended in terms of any alleged sui generis features of international relations' (Brown 2000: 91; emphases in original). Thirdly, however, for all his professed non-membership in the English School, when it comes to confronting its thought with theoretically quite different takes on international politics and world order, there is an impression that he would rather err on the English School side (see, for example, Brown 2004 in relation to systems theory). ${ }^{5}$

In ISGP, Brown once more seeks to distinguish his approach from those more prescriptive theorists of IPT. In so doing, he differentiates IPT from ethics and international affairs, though he certainly acknowledges the importance of those undertaking this work, for instance at the Carnegie Council for Ethics in International Affairs, and their house journal Ethics \& International Affairs. ${ }^{6}$ For Brown, though, his approach is that of a political theorist, one whose job is not to advocate for policy prescriptions but to interpret and clarify. This matches his call in the prologue to SRJ, in which he asks us to 'set out our values' a task sometimes assumed rather than undertaken.

In sum, Brown has framed and reframed IPT through these three texts. In so doing, he has developed the field of IPT in important and interesting ways. Admittedly, some issues and concerns slip through these frames, leaving us without his powerful insights into important matters such as world religion and the environment. But, despite these lacunae, Brown's understanding of IPT has shaped our understanding(s) and provides a powerful tool by which to interpret and evaluate the world around us.

\footnotetext{
${ }^{5}$ It's like not being a FC Southampton fan, but still favouring it over all the others (if it's not Chelsea, that is).

${ }^{6}$ One of Brown's early publications is in Ethics \& International Affairs, an effort to redefine Hegel for a generation of theorists who saw him as a foundation for German militarism; Brown 1991, reprinted in Brown 2010 .
} 


\section{Liberalism and Brown}

Brown is not associated with liberal IR theory or even liberal political theory. As indicated in the previous section, his work seeks to interpret the ways in which various IR theories assume certain normative agendas and/or value based assumptions. One of the dominant underlying theoretical assumptions in the study and practice of international relations is liberalism. As a result, IPT, as with many other theoretical approaches, might be read as a response to this underlying liberal agenda. Can we read Brown's work in a similar way?

Brown was influenced by one of the leading theorists of liberal political theory, Brian Barry. In saying this, however, Brown notes that the shape of his political theory (and perhaps political views) is closer to a communitarian thinker, Michael Walzer (Brown 2010: 4). ${ }^{7} \mathrm{He}$ notes in his intellectual biography that he read widely and, one can imagine, sympathetically a number of Marxist and critical theory works on global politics. And, as noted in the previous section, he was greatly influenced by the postmodernist theories of figures such as William Connolly. It is clear, though, that in reading through the corpus of his works, Brown is less sympathetic to those works today. One reason for this is his argument that there has been a 'loss of faith in rational discourse of the liberal left' (Brown 2010: 10), a category of scholars which includes both the critical/Marxist and postmodern perspectives. He is a strong critic of this failure of liberal theorist to think carefully through their presumptions and values, but at the same time he finds himself uneasy in this position. As he says,

Had I realised then that the natural defenders of the Enlightenment were going to make such a poor fist of the task over the next two decades, I would have been a lot less willing to endorse their critics. I suppose I am really acknowledging a degree of hypocrisy here; along with a great many late-modern writers, I surmise, I was willing to kick against liberal rationalism largely because I thought it would always be there. Part of the

\footnotetext{
${ }^{7}$ To call Walzer communitarian rather than liberal, though, distorts his views to some extent. While his work clearly has a strong communitarian orientation, he defends liberal ideas and practices in much of his writing and in his role as long time editor of Dissent magazine.
} 
story that unfolds in subsequent essays reflects a gradual realization that this might not be the case. (Brown 2010: 11)

This admission suggests that Brown sees part of his task as one of criticism, the kind of criticism described in the previous section, one of engaging in dialogue with others but only if they can engage in similar forms of critique. Liberalism provided a standard within which all such critique took place, but as Brown notes here, if the underlying rational discourse assumed by liberalism fails, then perhaps liberalism itself may need rescuing?

As expressed in this quote, though, Brown himself has been a rather pungent critic of many liberal assumptions. He acknowledges the importance of figures such as John Rawls (Brown 2002) and Charles Beitz (Brown 2005) in establishing liberal political theory and making it relevant for understanding the international realm. Indeed, he defends Rawls' turn to the international more than some students of Rawls, such as Beitz and Thomas Pogge. In an essay on liberalism and the globalization of ethics, Brown acknowledges liberalism's complexity, though he notes that it relies, ultimately, on the importance of the individual (Brown 2010 165). This essay explores one of the core dilemmas of liberalism, either domestic or international; the tension between the universalism of defending that individual and his/her rights and the necessity of accepting and tolerating differences among individuals and communities to pursue their own goals and life plans. This core liberal dilemma, one addressed by figures such as John Locke, informs much of Brown's scholarship. That is, seeking to negotiate this space between the particular and the universal constitutes a central dimension of Brown's work, and, one might argue, IPT more generally.

A different approach to this same issue comes out in Brown's reflections on human rights. His essay 'Universal Human Rights: A Critique' (Brown 2010) provides a powerful and important assessment of the problems surrounding human rights. Criticisms of the universality of human rights abound, but Brown's critique refuses to be a simple one of relativism. Rather, in a nuanced and powerful argument, he posits that human rights can only 
work in particular kinds of liberal societies, one from within which human rights defenders either write or act. Without this cultural context, human rights cannot be advanced globally. In making this point, he does not privilege the Western cultures which first generated rights, for he notes that they themselves have perhaps lost that culture; for instance, 'Americans have more and more rights, but less and less of a society within to exercise them' (Brown 2010 : 62). The conclusion of this chapter argues that, once more, liberal theorists need to better establish the theoretical foundations and assumptions that drive their advocacy of human rights. He concludes the chapter by arguing that only a focus on cultivating a particular kind of civil society will allow the emergence and protection of human rights.

On this point, we can suggest one way in which Brown's approach to IPT can be seen in relation to liberalism. He has cultivated a particular understanding of pluralism, one that does not accept all cultures as good or worth pursuing, but as potential points of argument and debate. This means that engaging in debates about human rights cannot proceed from an assured assumption of a human nature which by necessity desires freedom. Rather, true pluralism requires careful understanding of and engagement with others and one's own community. It requires judgment, for true judgment demands understanding not only the other but oneself. The final section of this introduction turns to this important political virtue in Brown's work.

\section{$\underline{\text { Political Judgment and Pluralism }}$}

Brown entitles his 2010 collection of essays, Practical Judgment in International Political Theory. The book does not present a theory of practical judgment, but includes five essays which 'represent the kind of practical-minded thinking that I wish to promote' (Brown 2010: 15). In those essays, which cover contested topics such as humanitarian intervention and pre-emptive military action, Brown exercises his own judgment in relation to ethical debates within the global realm. His judgements, particularly on the use of force, stand 
counter to many assumptions and arguments that have framed these debates among his fellow scholars of IR and IPT. For instance, Brown argues, unlike many, that it is legitimate to be selective about when to engage in humanitarian intervention, which stands in direct contract to those who argue that the consistency in these matters is fundamental to their moral legitimacy. And, in the matter of pre-emption, Brown argues that we cannot simply rule it out on legal grounds or through interpretive strategies which paint the US and UK use of this strategy in the Iraq war as evidence of the moral evil of Tony Blair or George Bush. He points out that the hatred for these two leaders does not necessarily 'build the capacity for making the right kind of judgment' (Brown 2010: 249).

The idea of practical judgement arises from a number of sources. Aristotle provides one well known formulation through his theory of the virtues. For Aristotle, the human condition is defined by two basic factors: our intellect and our communal living. These two things combined separate us from the rest of the physical world. For Aristotle, they also generate the two virtues that define what it means to be the best kind of person, the intellectual and practical virtues. In describing the virtues, Aristotle first explains the moral virtues, which are those shaped by habit and political life. They are designed to cultivate an ability to choose how to act, not how to think. Their importance derives from the fact that humans live in community and so must be able to act together. The second type of virtue is the intellectual one, which he treats in Book VI of the Nicomachean Ethics which is derived from is discussion of scientific reasoning found in the Posterior Analytics. Scientific reasoning entails thinking from first principles and the reasoning that follows from them results in knowledge that cannot be otherwise.

But reasoning must also take into account the particulars and the inductive process that provides a foundation for thinking. Scientific thinking is not the intellectual virtue on which Aristotle places his emphasis. Rather, it is deliberative thinking, or the dialectical process 
described in the Topics. Interestingly, Aristotle argues that practical deliberation should not lead us to downplay scientific reasoning, only that to be a fully happy human person we need the deliberative form of reasoning in order to move us toward action. Combined with habits and character of the moral virtues, the practical wisdom of deliberative excellence results in the good person.

Aristotle's account of the virtues relies on a particular place and time, that of the $4^{\text {th }}$ century BC Greek gentlemen scholar. Such a person no longer exists, and so perhaps we should not idealize this way of thinking. Indeed, his biology relies on assumptions about gender and generation that are fundamentally flawed, leading him to disparage the ability of women to achieve equality with men. Brown does not share those assumptions with Aristotle. Rather, Brown shares with Aristotle (and with many of the classical realists) the idea that any form of political reasoning must be dialectical rather than solely deductive and it must take into account the particulars of the situations within which such reasoning takes place. So, rather than being guided a universal liberal or legal logic to which all participants must agree in advance, Brown suggests a different form of reasoning, one which demands taking seriously the contexts, often very conflictual and even dangerous contexts, that shape world politics. Simple solutions based on Western ideals of human rights or the rule of law cannot be the sole way of thinking through the problems that bedevil the world today.

This brings us back to pluralism. As noted in the previous section, Brown is motivated in much of scholarship with trying to speak to a plural world. He demands that critical reflection take place among all participants. The standards against which such reflection take place are related to and perhaps unconsciously parasitic on broad liberal ideas, but Brown does not allow those to serve as trump cards. Rather, he argues for a form of deep pluralism, one that respects the capacity of all persons to engage in critical dialogue and reflection on theirs and others practices. We may not agree on all his political judgments, but his demand 
that we think carefully about how to go about making such judgments, is perhaps his most important contribution to the field of IPT.

\section{References}

Brown, C. (2000) 'The "English School”: International Theory and International Society', pp. 91-102 in M. Albert/L. Brock/K.D. Wolf (eds.) Civilizing World Politics. Society and Community Beyond the State (Lanham, MD: Rowman \& Littlefield).

Brown, C. (2004) 'The "English School” and World Society', pp.59-71 in M. Albert/L. Hilkermeier (eds.) Observing International Relations. Niklas Luhmann and World Politics (London: Routledge).

Brown, C. (2010a [1998]) 'Universal Human rights: A Critique' pp 53-71 in Practical Judgment in International Political Theory: Selected Essays (London: Routledge). Originally in Tim Dunne and N. J. Wheeler, eds., (1998) Human Rights and Global Politics (Cambridge: Cambridge University Press)

Brown, C. (2015) International Society, Global Polity: An Introduction to International Political Theory (Los Angeles: Sage)

Brown, C. (2017) "Revisionist Just War Theory and the Impossibility of a Moral Victory" in Cian O'Driscoll, Andrew Hom, and Kurt Mills, eds., Moral Victories: The Ethics of Winning Wars (Oxford: Oxford University Press)

Brown, C., Terry Nardin and Nicholas Rengger, eds., (2002) International Relations in Political Thought: Texts from the Ancient Greeks to the First World War (Cambridge: Cambridge University Press)

Brown, C. and Kristen Ainley (2004) Understanding International Relations, $4^{\text {th }} \mathrm{ed}$. (London: Palgrave) 
Buzan, B. (2004) From International to World Society? English School Theory and the Social Structure of Globalisation (Cambridge: Cambridge University Press)

Buzan, B. (2014) The English School: A Bibliography (version of 2 September 2014; available under https://de.scribd.com/document/277138693/The-English-School-aBibliography; last accessed on 22 September 2017).

Frost, Mervyn (1986) Towards a Normative Theory of International Relations: A Critical Analysis of the Philosophical and Methodological Assumptions in the Discipline with Proposals towards a Substantive Normative Theory (Cambridge: Cambridge University Press)

Frost, Mervyn (1996) Ethics in International Relations: A Constitutive Theory (Cambridge: Cambridge University Press) Lang, Jr, A. (2007) "Morgenthau, Agency and Aristotle" in Michael Williams, ed., Reconsidering Realism: The Legacy of Hans J. Morgenthau in International Relations (Oxford: Oxford University Press): 18-41 